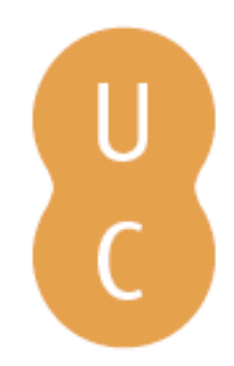

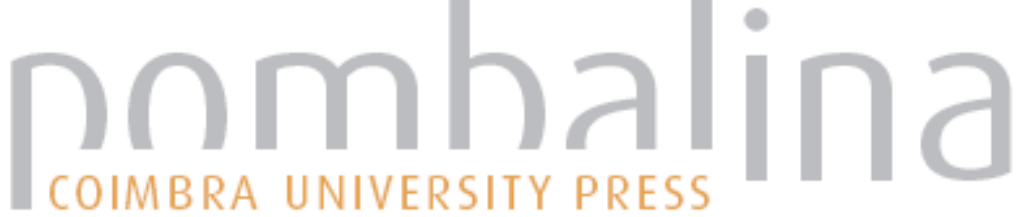

\section{Jornalismo, narrativas e escândalos}

Autor(es): $\quad$ Prior, Hélder

Publicado por: Imprensa da Universidade de Coimbra

URL

persistente: URI:http://hdl.handle.net/10316.2/41347

DOI: $\quad$ DOl:https://doi.org/10.14195/978-989-26-1324-6_6

Accessed : $\quad$ 26-Apr-2023 14:06:56

A navegação consulta e descarregamento dos títulos inseridos nas Bibliotecas Digitais UC Digitalis, UC Pombalina e UC Impactum, pressupõem a aceitação plena e sem reservas dos Termos e Condições de Uso destas Bibliotecas Digitais, disponíveis em https://digitalis.uc.pt/pt-pt/termos.

Conforme exposto nos referidos Termos e Condições de Uso, o descarregamento de títulos de acesso restrito requer uma licença válida de autorização devendo o utilizador aceder ao(s) documento(s) a partir de um endereço de IP da instituição detentora da supramencionada licença.

Ao utilizador é apenas permitido o descarregamento para uso pessoal, pelo que o emprego do(s) título(s) descarregado(s) para outro fim, designadamente comercial, carece de autorização do respetivo autor ou editor da obra.

Na medida em que todas as obras da UC Digitalis se encontram protegidas pelo Código do Direito de Autor e Direitos Conexos e demais legislação aplicável, toda a cópia, parcial ou total, deste documento, nos casos em que é legalmente admitida, deverá conter ou fazer-se acompanhar por este aviso.

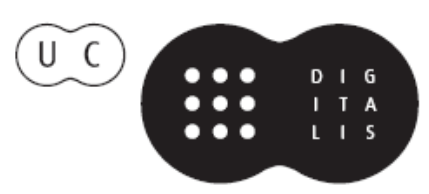





\title{
JORNALISMO, NARRATIVAS E ESCÂNDALOS
}

\author{
Hélder Prior
}

LabCom.IFP/UBI

Universidade de Brasília

\section{A actualidade do escândalo político}

Talvez não seja de todo despropositado iniciar esta reflexão intitulada Jornalismo, Narrativas e Escândalos, referindo que a vida pública das últimas décadas parece, definitivamente, marcada por uma sucessão de escândalos político-mediáticos. Podemos, com efeito, falar de uma cultura do escândalo político, ou de uma política do escândalo, na esfera pública contemporânea. Nesta era de grande visibilidade pública, o escândalo converteu-se numa característica incontornável da vida social e política de muitas democracias liberais, de tal forma que, devido à proliferação de denúncias que redundam em escândalos, parece que já não nos escandalizamos com quase nada. Etimologicamente, presume-se que o termo derive da raiz skand, que significa "surgir" ou "saltar", e apesar da palavra se ter tornado mais usual nos idiomas europeus a partir do século XVI, o vocábulo remonta ao período greco-latino. De facto, a palavra escândalo foi utilizada no Antigo Testamento Hebraico em sentido figurado para designar um "obstáculo", uma "armadilha", ou uma "ocasião de tropeço", de "queda 
no erro". No sentido teológico que encontramos quer no Antigo quer no Novo Testamento, escândalo significa "pedra de tropeço", "coisa que faz cair no mal" ou "ocasião de queda para os fracos". A teologia cristã colocou a ênfase do vocábulo na fragilidade dos indivíduos, daí as expressões "ocasião ou momento de queda", "obstáculo no caminho que leva uma pessoa à queda", "pedra de tropeço", "fazer cair em pecado" ou "dar motivo de censura" 56 .

Em inglês, a palavra scandal surgiu originariamente no século XVI e calcula-se que as palavras latinas escândalo, em português, escándalo, em castelhano, e scandalo, em italiano, tenham surgido aproximadamente na mesma época (Thompson, 2001: 30). Apesar do sentido herdado das Escrituras Sagradas, o termo acabou por adquirir uma significação mais sociológica do que propriamente teológica. Assim, e do ponto de vista sociológico, o escândalo pode ser interpretado como um "assassinato espiritual", como uma provocação aos valores que a sociedade partilha, derrogação dos valores reconhecidos e comungados pelos indivíduos dentro de um contexto societal específico. Não obstante o sentido religioso se ter mantido como um "momento de fraqueza" ou de "queda no erro", a conotação sociológica tornou-se mais comum. Deste modo, sociologicamente o escândalo implica a existência de valores partilhados por um determinado grupo social, a violação ou transgressão desses valores e, claro está, a existência de um público que reconhece essa violação e que se sente ofendido por ela, que se sente "escandalizado". O mesmo é dizer que não há escândalo sem a transgressão de certos valores, estereótipos morais, símbolos ou modelos sociais e, por outro lado, sem a propagação da transgressão e sem a existência de um público que se sente ofendido pelo comportamento escandaloso e que, por isso mesmo, o propaga, o publicita no espaço público.

$\overline{56}$ Conforme São Lucas, 7, 23; Isaías, 8, 15, Carta aos Romanos, 14,13. 
Na obra Political Scandal: power and visibility in the media age, John Thompson sublinha que o "escândalo implica certas formas de transgressão que são conhecidas por terceiros, formas de transgressão suficientemente graves ou sérias para provocar uma resposta pública de reprovação ou indignação" (2001: 32). Segundo o autor, normalmente os escândalos têm quatro características essenciais: 1) a sua existência implica a transgressão de certos valores, normas ou códigos morais; 2) a sua existência implica um elemento de segredo ou de ocultação, elemento que é desvelado e que chega ao conhecimento de indivíduos que não estão directamente implicados nas transgressões; 3) esses indivíduos reprovam essas ações e expressam publicamente os seus sentimentos de reprovação face a essas transgressões, tornando públicos os acontecimentos; 4) a revelação dessas ações ou acontecimentos pode afetar a reputação dos indivíduos responsáveis pelas transgressões entretanto publicitadas.

Apesar do escândalo não ser um fenómeno propriamente novo, o seu alcance, impacto e consequências transformou-se com o desenvolvimento das formas de comunicação mediática. O desenvolvimento dos meios de comunicação criou novas formas de publicidade distintas da publicidade em co-presença ou interação face a face, algo que, como sabemos, teve consequências na visibilidade pública dos dirigentes políticos, possibilitando que as suas mensagens pudessem chegar a uma multiplicidade de receptores que não partilham o mesmo espaço físico, mas que, por outro lado, também gerou novos riscos na gestão das fronteiras tradicionais que separavam os limites entre a esfera pública e a esfera privada.

Por outro lado, os escândalos, tal como se constituem na atualidade enquanto escândalos mediáticos, isto é, enquanto acontecimentos que são selecionados, enquadrados, divulgados e, porque não dizê-lo, moldados pela "máquina narrativa" dos meios de comunicação, devem-se a um conjunto de transformações políticas, sociais e económicas que ocorreram em finais do século XVIII e inícios 
do século XIX, transformações que contribuíram para converter a prática jornalística num campo de ação relativamente autónomo e independente face ao poder político, com uma ética profissional e códigos deontológicos específicos e, por outro lado, que incorporaram os princípios da visibilidade e da transparência na política face ao obscurantismo e face à prática dos arcana imperii ou segredos do poder que vigorou durante séculos. Talvez por isso, alguns jornais do século XVIII, como o Daily Courant, o Daily Post, ou o Daily Journal, já publicavam frequentemente alegações escandalosas sobre a atuação dos ministros do governo britânico. Mais tarde, após a fundação por Pulitzer do New York World e do New York Journal, os novos jornais, de cariz mais ligeiro, passaram a dedicar mais espaço a estórias sensacionais, a acontecimentos insólitos, ao desporto e a aspectos relacionados com a vida privada e com as aventuras pessoais dos dirigentes políticos. Foi o chamado surgimento da penny press e do yellow journalism, uma imprensa que percebeu, desde logo, que a extemporaneidade e espectacularidade inerentes aos escândalos facilmente promovem a adesão de públicos e a captura da atenção pública. É por isso que os escândalos facilmente preenchem os requisitos da lógica da chamada cultura mediática.

Não por acaso, Theodore Lowi considera que na esfera pública hodierna os escândalos políticos adquiriram um importante "valor de uso" na luta pelo "poder simbólico". Nas palavras do autor, o escândalo também é uma commodity que os meios de comunicação e os partidos políticos não podem deixar de explorar. Lowi fala de um certo "mercado do escândalo" (Lowi, 2004: 71) que parece caracterizar a política hodierna, uma mercado explorado quer pelos partidos políticos na luta pela conquista de credibilidade e assentimento, quer pelos meios de comunicação na disputa pela atenção pública. De outro modo, o jornalismo de investigação configura-se, desde o século XIX, como um tipo de jornalismo que atua por debaixo da superfície política, procurando desvelar o "poder invisível", na terminologia de 
Norberto Bobbio (2003), e contribuir para a visibilidade e transparência do poder político, assumindo uma postura vigilante que ficou conhecida por watchdog role of the press.

Porém, apesar da proliferação de escândalos políticos, não é possível dizer que este seja um fenómeno que se possa definir a priori. Se, em alguns casos, os escândalos políticos podem revelar casos de intransparência do poder público, publicitando situações de corrupção e desvios no exercício do poder político, em outros casos aquilo que sobressai é o papel dos meios de comunicação na revelação, publicitação e configuração de um acontecimento que, muitas vezes, se desenvolve como uma narrativa mediática que alimenta o imaginário do leitor ou espectador de produtos informativos. Ora, segundo Markovits e Silverstein, dois dos principais teóricos que trabalharam o fenómeno, o escândalo político poder-se-á definir como a violação dos procedimentos normativos que regulam o exercício do poder, resultando de uma clara tensão entre a lógica do poder, tendencialmente privada e secreta, e a lógica dos procedimentos normativos democráticos de natureza pública, no sentido de visível, de acessível, de algo que pode ser visto por todos (Markovits; Silverstein, 1988: 7). Na perspetiva dos autores, um escândalo político implica necessariamente a "violação do procedimento devido", isto é, a violação das normas e das convenções que regulam o exercício do poder. Neste sentido, os autores concluem que os sistemas políticos que favorecem a proliferação de escândalos políticos na sua essência são as democracias liberais, precisamente pelo facto de as democracias liberais se pautarem por normas e procedimentos normativos que têm uma sólida base institucional. "Se os escândalos políticos não existissem, as democracias liberais tê-los-iam inventado", concluem (1998: 9).

No seguimento das considerações de Markovits e Silverstein, John Thompson apelida este tipo de escândalos de "escândalos de poder", uma distinção terminológica que permite distinguir as transgressões dos procedimentos normativos que regulam o 
exercício do poder como uma forma peculiar de escândalo político. As outras formas ou tipos de escândalo político seriam os escândalos sexuais e os escândalos financeiros que envolvem ou afetam a reputação de dirigentes políticos. Tal como contundentemente assevera o sociólogo:

\begin{abstract}
Podemos distinguir três tipos fundamentais de escândalo na esfera política: aqueles que implicam a transgressão dos códigos sexuais (escândalos sexuais), aqueles que implicam uma má utilização dos recursos económicos (escândalos financeiros), e aqueles que implicam determinados abusos no exercício do poder político (escândalos de poder) (Thompson, 2001:168).
\end{abstract}

Não obstante, o próprio Thompson adverte que a eclosão de escândalos depende, em grande medida, do contexto cultural onde ocorrem as alegadas transgressões e da "força vinculativa" de determinadas normas sociais, força vinculativa que, naturalmente, varia de sociedade para sociedade. Uma vez que qualquer escândalo implica a existência de transgressões, deve referir-se que a variabilidade e diversidade cultural faz com que uma atividade possa resultar num escândalo num determinado contexto cultural e, num outro contexto, seja entendida como algo perfeitamente normal ou aceitável.

Por outro lado, a emergência ou eclosão de um escândalo na modernidade depende do grau de conhecimento público sobre as alegadas transgressões e, também, do grau de reprovação que essas transgressões geram na opinião pública. Neste ponto, o papel da comunicação mediática acaba por ser crucial no processo de publicitação e mediatização dos acontecimentos que estão, ou estiveram, na eclosão de um determinado escândalo. E, quando os desvios do poder político, quando as transgressões cometidas em segredo são denunciadas, enquadradas e divulgadas pelos meios de comunicação, 
gerando sentimentos generalizados de reprovação, o escândalo constitui-se enquanto acontecimento mediático.

O escândalo político confunde-se ou associa-se, muitas vezes, com práticas de corrupção no interior da vida pública. Porém, é importante fazer a distinção conceptual entre os dois termos. Segundo se pode ler no Dicionário da Língua Portuguesa Contemporânea, corrupção significa "decomposição", "putrefacção" ou "deterioração" dos valores morais ${ }^{57}$. Quando deslocado para a linguagem política, $\mathrm{o}$ ato de corrumpere refere a perversão do exercício do poder ou o seu mau uso nas tarefas públicas. Com efeito, para a corrupção se converta em escândalo é indispensável que a transgressão se transforme num elemento visível, se ofereça aos olhos do público. O escândalo apenas se constitui a partir do momento em que se forma um discurso acusatório sobre supostas atividades que causam sentimentos generalizados de desaprovação e repulsa. Por conseguinte, para que a corrupção se converta num escândalo é fundamental que os atos corruptos se revelem e despertem sentimentos de reprovação generalizada. Se a corrupção permanecer latente, ou, ainda que revelada, se não despertar sentimentos de indignação, o escândalo não poderá eclodir.

Ora, de acordo com a perspetiva que pretendemos erigir neste ensaio, a reconfiguração do escândalo político na esfera pública não é um processo aleatório, até porque o acontecimento sofre a ação do medium, isto é, desenvolve-se literalmente nos meios de comunicação e é moldado por eles. Do ponto de vista linguístico, é um processo fáctico, pois deve obedecer ao contrato cognitivo de veracidade face aos factos narrados, provocando os chamados "efeitos de real", mas também é um processo fictício, pois sabemos que os jornalistas exploram efeitos emocionais e expressivos para captar e manter a atenção do leitor,

\footnotetext{
${ }^{57}$ Cf. Dicionário da Língua Portuguesa Contemporânea, Primeiro Volume, Lisboa: Fundação Calouste Gulbenkian: Verbo, 2001, p. 994.
} 
combinando a objetividade com a subjetividade. No caso do escândalo, não devemos esquecer que este provoca, também, os chamados "efeitos de surpresa”, pois o escândalo político é um acontecimento que irrompe na esfera pública, que desequilibra o sistema político e social, escandalizando o público, mas que também desequilibra o próprio sistema dos media, uma vez que altera subitamente a agenda mediática e as próprias rotinas jornalísticas. Por conseguinte, as atividades específicas do campo dos media desempenham um papel determinante na publicitação, agendamento e configuração de um acontecimento que, na maioria das vezes, se constituiu como uma complexa narrativa mediática. Normalmente, os escândalos mediáticos têm uma estrutura temporal e sequencial que é marcada, decisivamente, pelo ritmo próprio dos meios de comunicação, pelas suas pautas de publicação e difusão, mas também pelo papel desempenhado por outras instituições, como as instituições políticas ou judiciais. Apesar dos escândalos mediáticos serem acontecimentos "abertos" ou imprevisíveis, é possível identificar quatro fases no que ao seu desenvolvimento sequencial diz respeito. A primeira é, obviamente, a fase prévia ao escândalo mediático, isto é, as transgressões ou os desvios que estão na base do fenómeno e que, quando reveladas, provocam a sua eclosão. Aqui, podemos incluir as atividades de investigação de jornalistas ou de organizações judiciais, atividades muitas vezes de rotina, mas que acabam por desvelar a quebra de normas ou de códigos sociais, jurídicos ou políticos.

A segunda é a fase da eclosão do escândalo propriamente dito e implica a denúncia pública de uma suposta transgressão. Refere-se à fase da mediatização do acontecimento em que os media acabam por concentrar a atenção pública no caso e mantê-lo na agenda público-mediática durante dias, semanas, meses ou até anos, como acontece no caso de escândalos juridicamente complexos que podem voltar à agenda mediática após um período de menor cobertura informativa. A terceira fase do escândalo mediático refere-se à sua culminação ou desenlace. Neste ponto, os protagonistas envolvidos podem assumir 
a sua culpabilidade no caso, podem assumir as transgressões, a exemplo do que fez Bill Clinton no escândalo sexual que envolveu a sua secretária na Casa Branca, ou, no caso da sua culpabilidade não ficar provada, os indivíduos implicados podem encetar uma batalha judicial contra alguns órgãos de comunicação social por eventuais danos no seu capital político ou na sua reputação. A quarta e última fase, na perspetiva de Thompson (2001: 107-112), diz respeito às consequências do escândalo. Aqui, os meios de comunicação e as próprias instituições políticas podem iniciar uma reflexão sobre os acontecimentos e sobre as suas implicações, discutindo reformas políticas que evitem as transgressões que estiveram na origem do fenómeno, e analisando o acontecimento mediante vários ângulos e várias interpretações, discutindo todos os detalhes da "estória".

\section{Escândalo mediático e Narratividade}

Os escândalos mediáticos são, normalmente, experiências complexas que vão sendo alimentadas pela máquina narrativa dos meios de comunicação. Após as denúncias públicas de que ocorreu algum tipo de transgressão que envolve uma qualquer figura pública, erige-se um certo discurso acusatório acerca das hipotéticas transgressões que, por outro lado, tendem a ser desmentidas pelos indivíduos que se encontram no epicentro do escândalo. De outro modo, em muitos casos as investigações policiais, jornalísticas ou jurídicas sobre as transgressões que estão na origem de um escândalo particular, desvelam novos tipos de transgressões, que Thompson apelida de "transgressões de segunda ordem", que não raras vezes têm uma relação tangencial com os acontecimentos que estiveram na base do fenómeno. Nestes casos, a complexidade, a cobertura mediática e o impacto social do escândalo aumentam consideravelmente e o acontecimento converte-se numa "narrativa com tramas e sub-tramas" 
(Thompson, 2001: 46) que se pode desdobrar em sub-escândalos ou, inclusivamente, em escândalos de maior envergadura que eclipsam, pelo menos do ponto de vista mediático, as chamadas "transgressões de primeira ordem". De certa forma, podemos asseverar que o escândalo apresenta uma dinâmica comunicativa que acaba por favorecer a mediatização e a dramatização do acontecimento. A atenção mediática sobre uma transgressão inicial pode conduzir o debate público para uma dialética de acusação versus defesa. De um lado, os meios de comunicação ou os indivíduos que se encontram implicados na denúncia de hipotéticas transgressões pugnam por uma certa culpabilização e moralização da vida pública; de outro lado, os indivíduos envolvidos no epicentro do escândalo procuram desmentir as acusações de que são alvo, acusando os jornalistas ou os opositores de perseguição, difamação ou aproveitamento político. No caso dos escândalos mais complexos, é previsível que das investigações iniciais surjam novos indícios ou novas revelações que acabam por adensar o debate público sobre o fenómeno, envolver novas transgressões e novas personagens, novas alegações públicas e desmentidos e, consequentemente, novos dados e revelações que acabam por aumentar a complexidade narrativa do próprio escândalo, o quadro enunciativo do acontecimento e a constituição de sentidos.

Como se sabe, os dispositivos mediáticos conferem marcas enunciativas aos acontecimentos e a configuração do escândalo nos media não escapa à lógica de refiguração inerente aos dispositivos de mediação simbólica. O escândalo desenvolve-se, literalmente, nos meios de comunicação mediante um processo de "tessitura da intriga", isto é, mediante a sucessão e o enquadramento dos eventos e das ações no tempo, transformando o acontecimento numa "estória" inteligível, numa "estória" que pode ser facilmente compreendida e apreendida pelo público. O sujeito narrador organiza os factos e os acontecimentos com o objetivo de construir uma totalidade inteligível e de, consequentemente, criar sentido. Compete ao jornalista 
organizar a experiência do escândalo, as sequências, a reconstituição no tempo de transgressões cometidas no passado, identificar os indivíduos implicados, as personagens, aproximando, naturalmente, a reconstrução do fenómeno à realidade, ao referente. Não devemos esquecer que o texto jornalístico é uma "recriação linguística" dos acontecimentos e o escândalo mediático, por ser normalmente um acontecimento complexo e disruptivo que se desenvolve durante vários dias, semanas ou meses, obedece a um plano de organização estrutural que se caracteriza pela sucessão dos eventos de forma encadeada e, naturalmente, segundo estratégias discursivas que organizam, contextualizam e explicam os acontecimentos que estão na base da sua eclosão.

Nesta linha de pensamento, a comunicação mediatizada, ao converter o escândalo num acontecimento selecionado, enquadrado e divulgado pelo medium, acaba por organizar a narrativa do escândalo sob a forma de intriga diegética. Na nossa perspetiva, os escândalos mediáticos apresentam uma dinâmica comunicativa que adquire significações e representações na medida em que a ação se vai reconfigurando, se vai reconstruindo na esfera mediática e nas notícias da imprensa. Neste processo de recomposição do escândalo, as componentes linguísticas ganham uma significação que possibilita a reconstrução do enredo jornalístico, a sua fragmentação, reconfiguração em episódios, em momentos de maior e menor cobertura mediática, em cenas e em personagens que realizam determinadas funções no desenrolar dos acontecimentos. Isso significa que podemos interpretar os escândalos mediáticos como narrativas complexas que se desenvolvem na imprensa, "estórias" que têm um enredo, episódios principais e secundários, personagens, e efeitos de sentido inerentes ao trabalho de recomposição do jornalismo no momento de converter o fenómeno numa experiência mediática, numa experiência instituída pelo campo da imprensa que pode ser apreendida e experimentada pelo público. 
O filósofo italiano Gianni Vattimo caracteriza este fenómeno de "mundo fantasmático dos mass media" (Vattimo, 1989), um mundo onde as notícias sobre os acontecimentos do mundo real surgem, muitas vezes, como uma "novela", como uma "fábula", uma intriga mediática urdida pelos jogos de linguagem que são inerentes ao jornalismo e que, mais do que representar meramente a realidade, a enquadram sob determinados ângulos, a moldam, a configuram, a instituem, atribuindo-lhes de forma seletiva particularidades ou características específicas.

A configuração narrativa do escândalo permite a experimentação da realidade, a fácil apreensão da complexidade dos acontecimentos e o estabelecimento de uma visão integrada do fenómeno. É a narratividade que ordena o acontecimento, que determina as suas conexões, que liga os eventos e os elementos dispersos, organizando, por conseguinte, o sentido. Tal como sublinha Ricoeur "as questões "quem", "o quê", "como", "porquê" e outras estão já contidas na inteligência narrativa" (1985: 35), e, neste sentido, a compreensão dos acontecimentos do mundo da vida faz-se pela via da narratividade, pois é a narrativa que reordena os acontecimentos e que contribui para a sua compreensão e explicação. Não obstante, é importante referir que a linguagem jornalística não recria exatamente o mundo da vida, o real, mas apenas consegue recompor essa realidade, produzindo um discurso verosímil, um "efeito de realidade". É por isso que os acontecimentos relatados acabam por estar fortemente impregnados de subjetividade, quer na sua enunciação, quer no ato de receção por parte do leitor/ espectador, ainda que a enunciação jornalística seja, naturalmente, caracterizada pela autenticidade expressiva do locutor. Por outro lado, deve acrescentar-se que a configuração narrativa dos acontecimentos públicos é fortemente marcada ou caracterizada por contextos pragmáticos e pelas pretensões do narrador no momento de costurar o ato narrativo. Assim, as narrativas de 
imprensa não são, com efeito, ingénuas ou construídas aleatoriamente, mas são, antes, caracterizadas pela atitude argumentativa do narrador, pelas conexões que este estabelece entre os eventos e, naturalmente, pelos efeitos de sentido que evoca nos destinatários. Mais do que relatar literalmente a realidade, as narrativas da imprensa estão impregnadas de jogos de linguagem que despertam uma certa experiência estética no momento da sua receção e apreensão, independentemente da necessária aproximação do discurso produzido à realidade objetiva, referencial. Todavia, e tal como contundentemente assinala Motta, "toda versão sobre o real é uma interpretação dele, e toda versão trai porque é uma versão entre tantas outras possíveis: não é o facto em si mesmo" (Motta, 2013: 40).

Produzindo efeitos fácticos ou fictícios, a configuração narrativa dos acontecimentos públicos construída pelo campo do jornalismo articula os antecedentes e os consequentes, as ações realizadas por personagens, as causas e as consequências dessas ações, a temporalidade e a serialidade dos acontecimentos, em suma, uma síntese de elementos heterogéneos e fragmentados que são colocados em relação, que são ordenados, configurados, convertidos numa totalidade que pode ser compreendida, apreendida pelos destinatários. No fundo, trata-se de estabelecer relações lógicas e causais entre acontecimentos passados, recorrendo a um encadeamento temporal e cronológico e a um conjunto de recursos explicativos que possibilitam quer a inteligibilidade, quer a "experimentação" dos acontecimentos.

Com efeito, a descrição do mundo prático da ação é possibilitada pela mise en intrigue, isto é, pela configuração e estruturação dos acontecimentos mediante uma rede de intersignificação que integra os elementos da ação numa lógica, numa composição ou totalidade inteligível. Como, a propósito, sublinha Adam, "a atividade narrativa combina uma ordem cronológica e uma ordem configuracional" 
(1984: 17) que integra elementos heterogéneos numa composição ordenada, articulando o acontecimento e, consequentemente, configurando-o. Neste ponto, os relatos informativos acabam por atribuir particularidades específicas ou determinados pormenores aos acontecimentos públicos, e fazem-no de forma "seletiva" (Tuchman, 2003: 97), produzindo, simultaneamente, sentidos culturais, políticos ou ideológicos. O jornalista assume-se como o sujeito enunciador, como a voz narrativa responsável pela interlocução e pela construção de posições factuais e referenciais, mas também por posições poéticas, estéticas e ficcionais.

\section{Quando o escândalo se converte em "estória": o caso Face Oculta}

Uma das funções primordiais dos media consiste em inscrever o fluxo dos acontecimentos na história, organizando para o leitor/ espectador os eventos do mundo da vida mediante sequências lógicas, ao mesmo tempo que alimentam o imaginário do público (Lits, 2008: 126). Se, neste texto, temos procurado interpretar os escândalos mediáticos como narrativas complexas que se desenvolvem na esfera pública devido à ação do medium, talvez seja pertinente, agora, ilustrar o nosso trabalho com uma breve análise pragmática de um dos escândalos mais mediáticos dos últimos anos da política portuguesa, o caso Face Oculta. Analisando a cobertura jornalística do Semanário Sol num período determinado, procuraremos demonstrar de que forma o ato de fala narrativo organizou o acontecimento, as suas sequências e episódios, a caracterização das personagens envolvidas e o uso de artimanhas enunciativas que tiveram como propósito criar efeitos de real e efeitos de sentido.

Efetivamente, por um lado, a análise do escândalo Face Oculta permite-nos observar a recomposição de notícias sobre um mesmo tema ou assunto num acontecimento eminentemente dramático onde 
é possível acompanhar o desdobramento de episódios, a caracterização de personagens, os papéis desempenhados, a presença de conflitos, enfim, a representação do real. Por outro lado, também nos permite compreender os escândalos mediáticos como narrativas, como "estórias jornalísticas" que se vão desdobrando em plots principais e secundários aos quais a poética jornalística vai acrescentando novos dados e aumentando a sua própria complexidade. O caso foi publicitado pela imprensa nos meses de outubro e novembro de 2009 e arrastou-se até setembro de 2014, altura em que todos os arguidos foram condenados. Como facilmente se constata, o escândalo teve um desenvolvimento temporal bastante longo, algo que se explica pelo facto de se ter constituído como um processo jurídico. Precisamente do ponto de vista judicial, foi dada como provada a existência de uma associação criminosa que obtinha, para a empresa O2 liderada por Manuel Godinho, benefícios em concursos públicos através de uma rede de tráfico de influências que envolvia altos quadros do Executivo liderado pelo primeiro-ministro de então, José Sócrates. Entre os 34 indivíduos acusados, encontrava-se Armanda Vara, ex-ministro pelo Partido Socialista e amigo de José Sócrates.

Do ponto de vista jurídico, o escândalo Face Oculta enquadra-se na tipologia de escândalo político-financeiro, pois revelou a existência de laços ocultos entre o poder político e o poder económico que serviriam para beneficiar empresas privadas mediante a má utilização ou má gestão de recursos públicos. Não obstante, das escutas telefónicas obtidas durante a investigação a Armando Vara, faziam parte conversas entre este protagonista e José Sócrates, conversas que, segundo o Ministério Público, levantavam suspeitas de que o governo teria tentado utilizar a empresa Portugal Telecom para comprar a estação televisiva TVI e, assim, influir no conteúdo das notícias veiculadas por este órgão de informação. Por outras palavras, e voltando à terminologia adotada por Thompson, as 
escutas telefónicas revelaram a existência de "transgressões de segunda ordem" que pouco tinham que ver com o escândalo político-financeiro e que envolviam, diretamente, o primeiro-ministro. Mediante a análise de nove edições do Semanário Sol sobre o tema, de 6 de novembro de 2009 a 12 de fevereiro de 2010, período em que a cobertura mediática foi mais intensa, é possível recompor as sequências do escândalo, identificar a presença de personagens, reordenar a cronologia jornalística, isto é, recompor um enredo, ligar as partes, unir as pontas-soltas, reconstruindo ou refigurando uma estória jornalística, a narrativa de um escândalo mediático. Como refere Motta, na esteira de Paul Ricoeur, "a reconfiguração do acontecimento-intriga tem o mágico poder de tecer a totalidade da estória e realizar a função de integração e de mediação da intriga" (Motta, 2013: 99). Ora, a complexidade e o desdobramento do escândalo tornam-se visíveis logo na edição de 6 de novembro de 2011. A informação de que o primeiro-ministro foi interceptado nas escutas a Armando Vara ganha destaque em relação ao que seria, tendencialmente, um escândalo financeiro. Por outro lado, a partir deste momento, José Sócrates, que não foi constituído arguido no caso, adquire uma certa proeminência na intriga. O Semanário Sol posiciona o então primeiro-ministro como uma das personagens do escândalo com a manchete: "Sócrates escutado em conversas com Vara". A edição acrescenta novos dados ao caso, ao referir que das escutas telefónicas efetuadas a Armando Vara surgiram "novos indícios" que foram enviados ao Procurador-Geral da República, Pinto Monteiro, indícios relacionados com o negócio PT/TVI. Nesta edição é, ainda, possível identificar a personalização do acontecimento mediante um enquadramento poético. Recorrendo a um frame lúdico em forma de teia com o título: "a teia de influências do Face Oculta", o jornalista personaliza o escândalo, posiciona as personagens, identifica os papéis desempenhados por estas, as suas funções: 


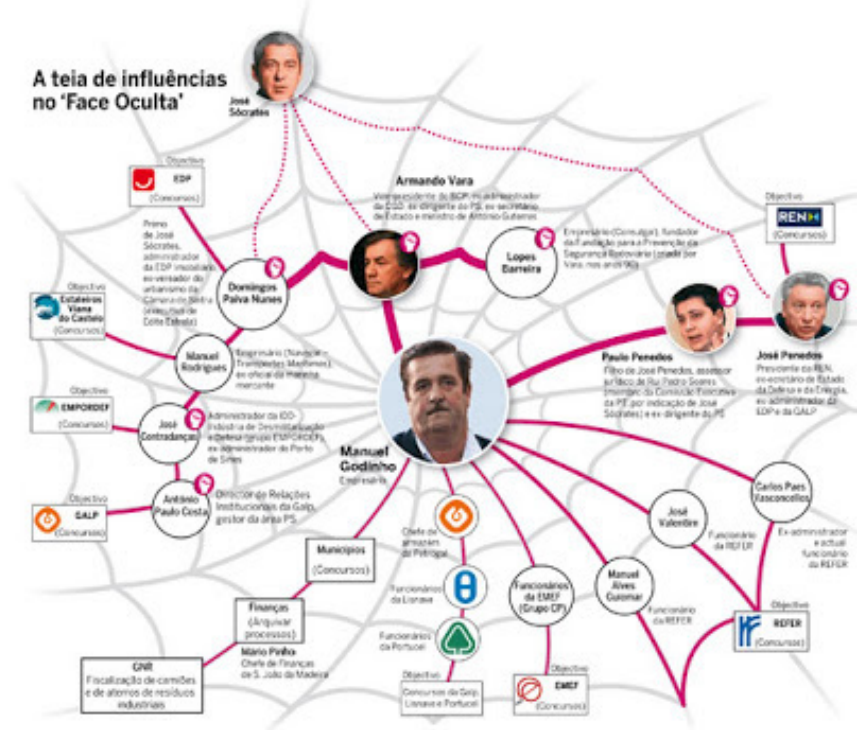

Figura 1: A teia de influências do Face Oculta. Semanário Sol, 6/11/2009.

Os actantes são identificados na narrativa mediante o posicionamento que o jornalista lhes confere, mediante uma certa hierarquia que visa despertar determinados efeitos no leitor. As personagens são colocadas em relação umas com as outras e tendo em conta o papel que cada uma desempenha na intriga. José Sócrates, apesar de não estar indiciado de quaisquer crimes, é identificado como aquilo que podemos designar por "actante dominante", verificando-se uma certa proeminência que o então primeiro-ministro acabou por adquirir no relacionamento estabelecido entre todos os envolvidos. As narrativas necessitam de personagens e o escândalo mediático tem, necessariamente, as suas dramatis personae, personagens que realizam determinadas ações e que, no caso específico do escândalo, são identificados como "transgressores" ou "purificadores", como vilões ou heróis.

Nas edições seguintes e à medida que são acrescentados novos dados ao escândalo, a narrativa mediática reconfigura-se, ganha 
novos episódios e novos conflitos. Cruzando o teor das conversas filtradas entre Sócrates e Armando Vara sobre a possibilidade de a PT comprar a TVI, com declarações públicas do primeiro-ministro prestadas num debate parlamentar no dia 24 de junho de 2009, o jornal acrescenta "transgressões de segunda ordem" à narrativa concluindo que "José Sócrates mentiu ao Parlamento sobre a TVI". De um escândalo eminentemente político-financeiro, o Face Oculta converte-se num escândalo de poder, num evento politizado que envolve a derrogação dos procedimentos normativos que regem o exercício do poder político. A edição de 13 de novembro de 2009 recorre ao flashback para recuperar o momento em que José Sócrates declarou, perante os deputados, não ter conhecimento das negociações entre a PT e a Prisa, dona da TVI, desconhecimento contrariado pelas escutas do processo Face Oculta, nomeadamente por uma conversa ocorrida em março desse mesmo ano entre o ex-primeiro-ministro e Armanda Vara. O narrador recorre ao frame temporal e cronológico para legitimar a sua fala, isto é, comprovar as novas transgressões. Reconstruindo os momentos mais significativos deste episódio, o jornalista recupera declarações proferidas no passado, resgata os antecedentes, para chegar à significação, à conclusão: "Sócrates mentiu no Parlamento”. Efetivamente, o momento da hipotética mentira parlamentar de José Sócrates constituiu-se como uma unidade temática do escândalo relativamente autónoma em relação "às transgressões de primeira ordem", podendo distinguir-se como um episódio ou uma parte da estória. Não obstante, trata-se de um episódio que ofereceu uma nova dinâmica à estória e que, de certa forma, fez progredir a narrativa mediática na direção de novas transgressões, animando e adensando o debate público. Novas transgressões que haveriam de ser divulgadas durante o mês de fevereiro, momento em que o caso adquiriu outros contornos devido à divulgação do conteúdo das escutas telefónicas entre Armando Vara e José Sócrates. A edição de 5 de fevereiro, intitulada "As escutas proibidas", revela a existência de 
um plano que envolvia o primeiro-ministro para controlar a estação televisiva e outros órgãos de informação. Se, num primeiro momento da narrativa, a operação judicial denominada Face Oculta começou por ter como objeto apurar as atividades ilícitas resultantes de uma "rede tentacular" que visava beneficiar as empresas de Manuel Godinho na adjudicação de obras públicas, as escutas telefónicas efetuadas a Armando Vara revelaram a existência de situações marginais ao escopo da investigação que, pelo seu conteúdo, representavam "um sério atropelo aos mais elementares princípios por que se devem nortear os Estados democráticos" $" 58$.

De acordo com as novas denúncias que são acrescentadas ao escândalo, o plano passava por afastar a jornalista Manuela Moura Guedes da TVI, aparentemente porque às sextas-feiras Manuela Moura Guedes abria o Jornal Nacional com notícias incómodas para o Governo relacionadas com um outro escândalo, o caso Freeport. ${ }^{59}$ Porém, e uma vez que para afastar Manuela Moura Guedes da TVI era necessário afastar o diretor da estação de Queluz e marido da jornalista, José Eduardo Moniz, a operação visava tomar conta da TVI através da Portugal Telecom, empresa da qual o Estado português era acionista. A cobertura jornalística reconfigurou o caso numa nova narrativa, mais complexa, com novos episódios, novos conflitos e novas personagens. Na mesma edição, é notório como a reconfiguração do escândalo denota uma relação recíproca entre a narratividade e a temporalidade dos acontecimentos. O plano ou "esquema" é situado no tempo mediante uma extensão cronológica de desdobramento da ação em certos momentos. É, justamente, neste

\footnotetext{
${ }^{58}$ Veja-se o despacho do diretor da Polícia Judiciária de Aveiro, Teófilo Santiago, de 12 de junho de 2009 .

${ }^{59} \mathrm{O}$ nome de José Sócrates esteve associado a um outro escândalo mediático, o caso Freeport. José Sócrates tornou-se num dos suspeitos de corrupção devido a ter subscrito, enquanto ministro do Ambiente, o decreto-lei que permitiu a aprovação da construção do outlet Freeport, em Alcochete. Algumas testemunhas declararam que o então ministro do Ambiente recebeu pagamentos em dinheiro, "luvas", para viabilizar o projeto. Porém, do caso não resultou nenhuma acusação.
} 
ponto, que a temporalidade surge ligada ao próprio desenvolvimento da intriga, isto é, à capacidade de organizar os acontecimentos e, assim, contar uma "estória" unificada. O quando e o como convertem-se em elementos constitutivos da narrativa do escândalo, especificamente porque permitem situar o leitor no tempo dos acontecimentos, ajudar o jornalista/narrador a organizar o tempo enunciativo e, por conseguinte, o discurso jornalístico. É a experiência do tempo que permite que o escândalo adquira uma certa unidade, organizando os episódios em sequências que geram a compreensão e a significação do fenómeno. Expressões temporais como "no dia seguinte", "estava-se a 19 de junho", ou "nesse mesmo dia", possibilitam a reconstrução da ação, a organização das sequências que compõem o enredo e, consequentemente, o estabelecimento de uma conexão interna que é essencial para a reconfiguração mediática do fenómeno.

Desta dramatização inerente à narrativa, as personagens e a sua caracterização surgem novamente como eminente categoria, como uma categoria responsável pelo desempenho do enredo. Com efeito, o relato surge mediante a identificação e a caracterização das personagens envolvidas no escândalo. Todavia, é notório que o narrador procura colocar as personagens em relação, descrevendo cada personagem tendo em conta as relações que esta estabelece ou estabeleceu com os demais envolvidos. O rosto das personagens é colocado não apenas em destaque, mas também em relação, um frame visual que permite a identificação dos envolvidos como "transgressores". O frame visual é acompanhado pela legenda: "os pivôs do esquema".

Neste processo de identificação e caracterização das personagens, Rui Pedro Soares ${ }^{60}$, por exemplo, é descrito como um "boy socrático", como um indivíduo que, apesar de ter "falta de curriculum",

\footnotetext{
${ }^{60}$ Rui Pedro Soares era o homem de confiança do governo na Portugal Telecom. Nomeado pelo executivo liderado por José Sócrates para o cargo de administrador, foi um dos responsáveis pela planificação da tentativa de compra da TVI pela PT.
} 

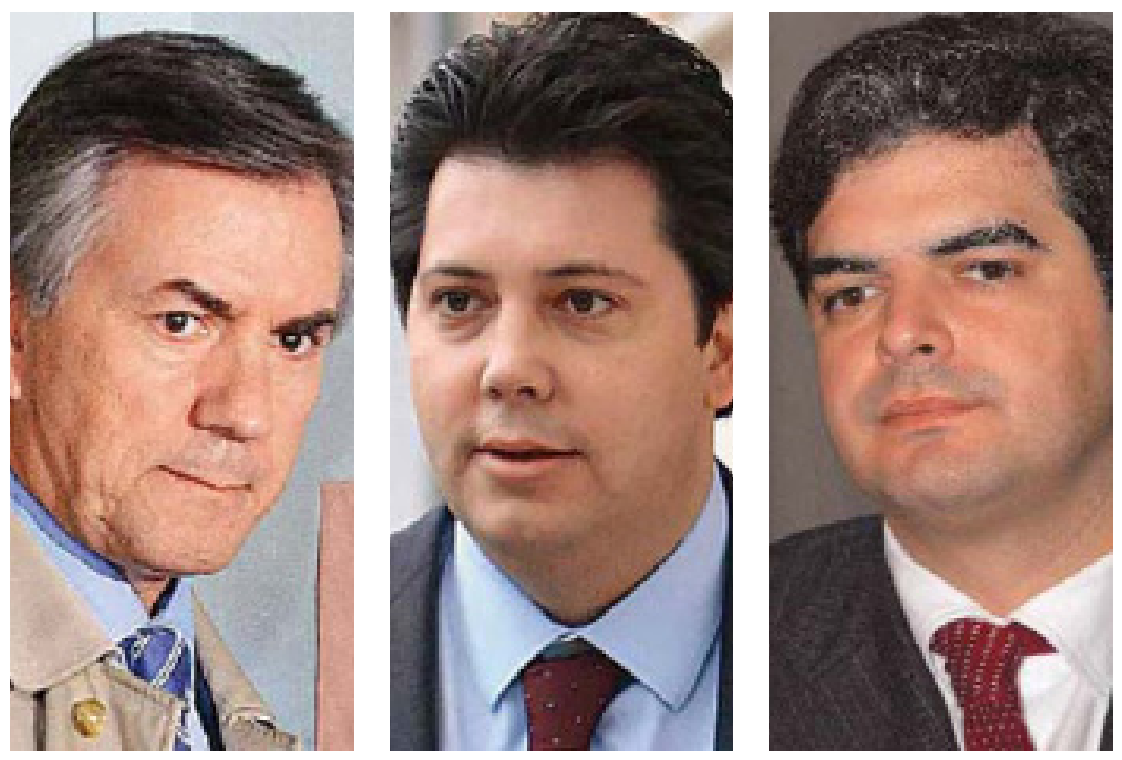

Figura 2: "Os pivôs do esquema" segundo o Semanário Sol de 5 de fevereiro de 2010.

se afirmou na empresa de telecomunicações devido à confiança em si depositada por José Sócrates. Não obstante, na identificação dos elementos-chave do escândalo, o ex-primeiro-ministro surge, novamente, como a figura central da narrativa, como o eixo do conflito em torno do qual toda a intriga se desenvolve. A centralidade de José Sócrates no escândalo torna-se de novo explícita na edição de 12 de fevereiro de 2010. Através de uma manchete metafórica, José Sócrates é identificado como a figura central da narrativa, não obstante o facto de não ter sido constituído arguido no processo. Trata-se de um enquadramento lúdico que visa significar que José Sócrates agiu de forma similar ao polvo, construindo uma "rede tentacular" que visava o controlo de meios de comunicação. Um efeito poético que ornamenta a realidade e que, simultaneamente, desperta efeitos de sentido no público. Uma estratégia intencional do narrador que ajuda a identificar Sócrates como o "actante dominante", mas que 


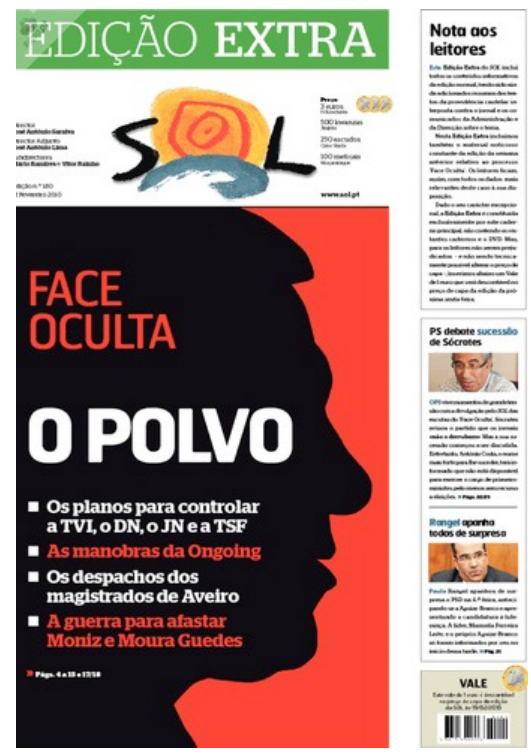

Figura 3: Manchete metafórica do Semanário Sol. 12 de fevereiro de 2010.

também ajuda a capturar a atenção pública ao gerar no público, de forma intencional ou não intencional, efeitos estéticos ou poéticos.

Como vemos, a linguagem narrativa convida o leitor ou espectador a fazer interpretações subjetivas, embora a linguagem jornalística privilegie recursos de estilo de caráter mais denotativo que conotativo, no sentido de gerar no destinatário uma apreensão quase imediata da mensagem, por motivos de economia discursiva. E, no quotidiano, a metáfora do polvo é uma das figuras de estilo mais utilizadas, sobretudo no que a assuntos da política diz respeito. De facto, a linguagem jornalística está repleta de metáforas convencionais, figuras de estilo que contêm o mínimo de "ruído" possível e que, além de ornamentarem ou embelezarem o discurso jornalístico, também assumem uma posição referencial. Efetivamente, a recomposição do escândalo nos media é quase sempre bastante rica em 
efeitos simbólicos, precisamente devido ao facto de o escândalo ser um acontecimento eminentemente dramático que suscita, no público, diversos estados de espírito.

\section{Considerações Finais}

Jornalismo, Narrativas e Escândalos procurou abordar as relações entre o jornalismo e a teoria da narrativa colocando em evidência as características eminentemente dramáticas e estéticas dos escândalos mediáticos. Na perspetiva que procurámos erigir, os escândalos mediáticos desenvolvem-se na esfera pública como narrativas complexas que têm conflitos, episódios, personagens e efeitos de sentido inerentes ao trabalho jornalístico de recomposição da realidade. O escândalo mediático apresenta-se como um processo "aberto", como um jogo de significações que adquire um certo valor expressivo e esteticizante ao configurar-se nos dispositivos de mediação simbólica. Ao apropriar-se do acontecimento para o converter em algo inteligível para o leitor, o medium combina, muitas vezes, as técnicas jornalísticas com as técnicas do universo ficcional para produzir narrativas dramáticas sobre os acontecimentos, particularmente sobre os acontecimentos da política. Neste ponto, acreditamos que os escândalos mediáticos apresentam uma dinâmica comunicativa que acaba por favorecer a sua dramatização, a sua reconfiguração numa trama, numa diegese. Com efeito, a desconstrução hermenêutica do escândalo Face Oculta demonstra que, muitas vezes, a informação surge como "novela" episódica organizada temporalmente e de onde emergem conflitos, personagens, momentos dramáticos, situações de suspense que amarram o leitor à estória e que o convidam a seguir a sua serialidade. É nesta perspetiva que consideramos que os escândalos mediáticos adquirem um enquadramento narrativo 
visível na organização textual do fenómeno, na sua fragmentação em episódios principais ou secundários, na personalização ou individualização da cobertura mediática, na definição da temporalidade dos acontecimentos, dos seus antecedentes e consequentes e numa certa composição poética inerente aos estratagemas enunciativos e à habilidade estilística do narrador/jornalista no momento de costurar o fenómeno como acontecimento mediático.

\section{REFERÊNCIAS BIBLIOGRÁFICAS}

AA.VV. (2011). Dicionário da Língua Portuguesa Contemporânea. Lisboa: Calouste Gulbenkian.

ADAM, J.M. (1984). Le Récit. Paris: Presses Universitaires de France.

ADAM, J-M; REVAZ F. (1997). A Análise da Narrativa. Lisboa: Gradiva. Apostolides, P; Williams, J.A. (2004). Public Affairs, Politics in the Age of Sex Scandals. London: Duke University Press.

ARISTÓTEleS (2005). Poética. Lisboa: Imprensa Nacional Casa da Moeda. BARTHES, R. (1973). O Prazer do Texto. Lisboa: Edições 70.

BIRD, E.; DARDENNE, R. (1999). "Mito, Registo e Estórias: explorando as qualidades narrativas das notícias", in TRAQUINA, N. (Org). Jornalismo, Questões, Teorias e "Estórias" Lisboa: Vega.

BObBIO, N. (2000). Teoria Geral da Política, a Filosofia Política e as Lições dos Clássicos, Rio de Janeiro: Elsevier Editora.

BOURDIEU, P. (1997). Sobre a Televisão. Oeiras: Celta Editora.

DAMPIERRE, E. (1954). "Thémes por l'étude du scandale", in Annales, Économies, Sociétés, Civilisations, $9^{\text {ème }}$ année, $\mathrm{N}^{\mathrm{o}} 3$.

DERRIDA, J; STIEGLER, B. (1996). Échographies de la télévision. Paris: Gallilée. LITS, M. (2008). Du Récit au récit médiatique. Bruxelles: De Boeck.

LOWI, T. (1988). "Prefácio", in MARKOVITS, A; SILVERSTEIN, M. (Org). The Politics of Scandal: Power and Processes in Liberal Democracies. New York: Holmes\&Meier Publishers. 
LOWI, T. J. (2004). "Power and Corruption, Political Competition and the Scandal Market", in APOSTOLIDIS, P.; Williams, J. A. (Org). Public Affairs, Politics in the Age of Sex Scandals. London: Duke University Press.

MARKOVITS, A; SILVERSTEIN, M. (Org). (1988). The Politics of Scandal: Power and Processes in Liberal Democracies. New York: Holmes\&Meier Publishers.

MOTTA, L.G, "Análise Pragmática da narrativa jornalística", in LAGO, C.; BENETTI, M. Metodologia da pesquisa em jornalismo. Petropólis: Vozes.

MOTTA, L.G. (2013). Análise Crítica da Narrativa. Brasília: Editora UNB.

PRIOR, H. (2013). Esfera Pública e Escândalo: o secreto no âmbito público. Tese de Doutoramento, Covilhã: Universidade da Beira Interior.

RICOEUR, P. (1983). Temps et Récit I. Paris: Le Seuil.

RICOUER, P. (1985). Temps et récit III, Le temps raconté. Paris: Le Seuil.

RICOEUR, P. (1999). Historia y Narratividad. Barcelona: Paidós.

RODRIGUES, A.D. (1984). O campo dos Media, Discursividade, Narratividade, Máquinas, Lisboa: Vega.

SEARLE, J.R. (2004). The Philosophy of language. Oxford: Oxford University Press. TODOROV, T. (1982). "Las categorias del relato literário", in Analisis Estructural del Relato. Barcelona: Ediciones Buenos Aires.

THOMPSON, J. B. (2001). El escándalo político: poder y visibilidad en la era de los medios de comunicación. Barcelona: Paidós.

TUCHMAN, G. (1999). “Contando estórias”, in TRAQUINA, N. (Org). Jornalismo, Questões, Teorias e "Estórias". Lisboa: Vega.

TUCHMAN, G. (2002). "As notícias como uma realidade construída", in ESTEVES, J.P. Comunicação e Sociedade. Lisboa: Livros Horizonte.

VATTimo, G. (1992). A Sociedade Transparente. Lisboa: Relógio D’água. 